\title{
The effects of kefir grain and starter culture on kefir produced from cow and buffalo milk during storage periods
}

\author{
Oktay TOMAR ${ }^{1 *}$ (D), Gökhan AKARCA¹, Abdullah ÇAĞLAR ${ }^{1}$, Mehmet BEYKAYA², Veli GÖK³
}

\begin{abstract}
The present study was aimed to determine the effect of different types of milk and kefir grains or starter cultures on the chemical properties, and microorganism counts of kefir samples. The type of milk had a significant effect on the acidity, dry matter, protein, and $\mathrm{CO}_{2}$ values. Acidity and $\mathrm{CO}_{2}$ values increased during storage period, while dry matter, fat and protein contents decreased. However, the type of milk had no significant effect on Lactobacillus, Leuconostoc and yeast counts. In the samples produced using starter culture microorganism counts except those of $L$. acidophilus of the samples increased $(\mathrm{p}<0.05)$ during the 14 days of storage. Higher Lactobacilli $(8.52 \mathrm{log} \mathrm{cfu} / \mathrm{ml})$ and Lactococci $(8.84 \mathrm{log} \mathrm{cfu} / \mathrm{ml})$ was found in kefir produced using buffalo milk and starter culture in 21 days of storage, while higher L. acidophilus $(6.41 \mathrm{log} \mathrm{cfu} / \mathrm{ml})$ was found in kefir produced using cow milk and starter culture. In general, due to the higher dry matter and protein content and yeast population, kefir made from buffalo milk may be preferred.
\end{abstract}

Keywords: buffalo milk; yeast; protein content; fermentation; acidity.

Practical Applications: Fermented milk beverages can be produced by traditional means throughout the world and can be produced and marketed industrially. Kefir production is divided into 2 categories as traditional and industrial methods. The main difference between these techniques is the use of kefir or starter culture in production. Kefir grains are mostly used for traditional kefir production. Due to the variable microflora in the kefir grains, the sensory properties of the Kefir samples may vary depending on the origin of the grains and conditions of storage and handling. Buffalo milk differs from other milk not only in terms of taste, but also chemically. Calcium and protein ratio is high and has less cholesterol content than cow's milk.

\section{Introduction}

Milk is of great importance for public health as it contains rich nutritional components (Yilmaz-Ersan et al., 2018). Milk is a significant source of calcium, phosphorus, and riboflavin. Moreover, it is of importance with its amino acid and fatty acid contents (Metin, 2012). The ideas to prevent microbiological deterioration and to increase the shelf-life and processing of different products with different flavors and aromas have increased the value of fermented and probiotic dairy products. Consumers accept and appreciate the continuously developing and diversifying dairy product sector (Tripathi \& Giri, 2014).

Kefir, a fermented dairy product, is a beverage produced by fermentation of lactic acid bacteria and yeasts. Kefir grains, which contain various microorganisms, are used in kefir production (Gao \& Li, 2016). The chemical, microbiological, and aromatic properties of kefir are formed by the co-operation of many bacteria as well as yeast in kefir grains (Farnworth, 2008). Kefir produced in different production areas varies in taste and aroma due to the different microorganisms in different kefir grains and in various production areas. To eliminate this difference in taste and aroma, the use of starter cultures has become widespread in producing kefir in recent years. However, chemical, microbiological and sensorial differences exist in kefir production with kefir grains or starter cultures (Barukčić et al.,
2017). Particularly in industrially produced kefir, the yeast taste is less prominent; however, it is more viscous than the kefir which is produced traditionally (Nielsen et al., 2014). Kefir grains contain complex symbiotic cultures of various bacteria and yeasts. These cultures affect the therapeutic properties of kefir as well as sensory properties. In contrast, commercial kefir cultures may have lower therapeutic characteristics than traditional kefir due to absence of some bacteria and yeasts (Barukčić et al., 2017).

Along with kefir grains and starter culture, milk used in the production of kefir plays a significant role in terms of properties and bioactive components of kefir (Öner et al., 2010). Various studies have been carried out on the use of different types of milk (cow, goat, sheep, and buffalo) in kefir production and different results have been found regarding the quality parameters and sensory characteristics of the kefir samples. (Wojtowski et al., 2003; Cais-Sokolińska et al., 2008). Buffalo milk contained higher dry matter, fat, and calories, and mineral, vitamins, and microelements than cow milk and had more nutritional value compared to other milk types thanks to its $7 \%$ to $9 \%$ fat content, high protein, high mineral content and partially low cholesterol ratio (Borghese, 2012). There are few studies on the use of buffalo milk in kefir production (Gul et al., 2015; Tomar \& Akarca, 2018; 
Gul et al., 2018). Gul et al. (2018) found in their study that buffalo milk kefir had higher viscosity and consistency index than cow's milk. The researchers stated that the use of buffalo milk improved the sensory and color properties of the kefir.

In recent years, kefir has come to prominence with the increasing tendency of consumer awareness of healthy foods. Several studies have reported that the consumption of kefir reduced the risk of illness and boosted the immune system (Moreno de Le Blanc et al., 2008). The present study aimed to investigate and compare the effects of cows' and buffalo milk on some properties of kefir made with kefir grains and starter culture

\section{Materials and methods}

Kefir grains were provided by the Pilot Dairy Plant at Ankara University, Agricultural Faculty (Ankara) Turkey, and commercial kefir starter culture, which contained Lactococcus lactis Spp. cremoris, Lactococcus lactis Spp. lactis, Lactococcus lactis Spp. lactis var. diacetylactis, Leuconostoc Spp., Debaryomyces hansenii, and Streptococcus thermophilus, was obtained from Chr. Hansen Inc. (FD-DVS EXACT Kefir 2, Denmark). The grains were stored at $-18{ }^{\circ} \mathrm{C}$ and used after reactivation by successive subcultures in milk from a local market that was treated at ultrahigh temperatures. To produce kefir, raw buffalo and cow milks were supplied by a local market in Afyonkarahisar, Turkey.

\subsection{Kefir production}

The fat ratios of cow milk (3.32\% fat, $11.25 \%$ dry matter, $3.47 \%$ protein, $7.01^{\circ} \mathrm{SH}$ acidity), and buffalo milk (7.23\% fat, $17.13 \%$ total solids, $4.52 \%$ protein, $8.55^{\circ} \mathrm{SH}$ acidity) were standardized to $3 \%$ with a cream separator. Standardized milk was exposed to heat treatment for $5 \mathrm{~min}$ at $90^{\circ} \mathrm{C}$. Temperature was controlled using a circulator water bath at $90^{\circ} \mathrm{C}$. Milk samples were cooled to $22^{\circ} \mathrm{C}$ immediately after heat treatment. At this temperature, $2 \% \mathrm{w} / \mathrm{v}$ kefir grains or starter culture $(0.015 \mathrm{~g} / \mathrm{L})$ were added to the milk separately. The milk samples were incubated at $22^{\circ} \mathrm{C}$ and the incubation ended at $\mathrm{pH}$ 4.6. Following the incubation, the kefir grains were separated from the kefir using a sieve. Kefir samples were cooled and filled into $250 \mathrm{~mL}$ colored glass bottles under aseptic conditions. All the kefir samples were stored at $4{ }^{\circ} \mathrm{C}$ for 21 days. The kefir samples which were produced using cow milk (CM) and buffalo milk (BM) with kefir grains $(\mathrm{G})$ were coded as CMG and BMG, respectively. Other kefir samples which were produced using cow milk (CM) and buffalo milk (BM) using starter culture (S) were coded as CMS and BMS, respectively.

\subsection{Chemical analyses}

Dry matter (DM) was determined according to the Association of Official Agricultural Chemists International (AOAC) Standard No. 990.20 (Association of Official Analytical Chemists, 2012a). Titratable acidity was determined according to AOAC Standard No. 947.05 and expressed as the percent of lactic acid (Association of Official Analytical Chemists, 2012b). Fat content in the kefir samples was measured according to AOAC Standard No. 2000.18 using the Gerber Method. (Association of Official Analytical Chemists, 2012c). The protein content of the kefir was measured using the method of Kjeldahl according to AOAC Standard No: 991.20 (Association of Official Analytical Chemists, 2012d). $\mathrm{CO}_{2}$ content was analyzed using the titrimetric method (Turkey, 1988).

\subsection{Microbiological methods}

Ten-gram kefir samples were aseptically taken. Sterilized Ringer's solution at a dilution of 1:9 (w/v) was added, and the samples were homogenized for $3 \mathrm{~min}$ in a stomacher Lab-Blender 400 (London, UK). The serial decimal dilutions were prepared in buffered peptone water and plated for bacterial counts.

Lactobacillus was counted on de Man Rogosa and Sharpe medium (Merck 1.10660) at $30^{\circ} \mathrm{C}$ under anaerobic conditions (5\% $\mathrm{CO}_{2}$ ) for $3 \mathrm{~d}$. Lactococcus was counted on M17 medium from Merck at $37^{\circ} \mathrm{C}$ under anaerobic conditions for $2 \mathrm{~d}$. Leuconostoc Spp. was counted on de Man Rogosa Sharpe Agar (Merck) incorporated with vancomycin hydrochloride (Sigma-Aldrich, St Louis, MO, USA) at $30^{\circ} \mathrm{C}$ for $3 \mathrm{~d}$. Lactobacillus acidophilus was counted on MRS-sorbitol Agar (Merck 1.10660) at $37^{\circ} \mathrm{C}$ under anaerobic conditions for 24-48 h. (Tomar et al., 2018). Yeasts were cultured on potato dextrose agar (Merck, 1.10130) ( $\mathrm{pH} 3.5$ ) with $10 \%$ added tartaric acid (Akarca et al., 2016).

\subsection{Statistical analyses}

The research design was completely randomized, having a factorial structure $(2 \times 2 \times 4)$. The factors were milk type (cow and buffalo), method (kefir grain and starter culture), and storage time $(1,7,14$, and $21 \mathrm{~d})$. A three-way analysis of variance was conducted on the data and analyzed using SPSS 16.0 (SPSS Inc., Chicago, IL, USA). Lsmeans values were generated and corresponding Duncan multiple comparison test was conducted. The treatment structure was completely randomized with two replications.

\section{Results and discussion}

\subsection{Chemical analysis}

Table 1 shows the variance for all factors affecting the chemical properties of the kefir samples. The type of milk played a crucial role in following contents: the acidity $(\mathrm{p}<0.0001)$, dry matter $(\mathrm{p}<0.0001)$, protein $(\mathrm{p}<0.0001)$ and $\mathrm{CO}_{2}(\mathrm{p}<0.001)$. The method used for kefir production (kefir grains or starter culture) and storage time affected the acidity $(\mathrm{p}<0.001)$, protein $(\mathrm{p}<0.001)$, and $\mathrm{CO}_{2}(\mathrm{p}<0.001)$ values to a great extent. No interaction was found among the factors affecting the chemical properties of kefir samples $(\mathrm{p}<0.05)$ (Table 1$)$.

The acidity, dry matter, fat, protein and $\mathrm{CO}_{2}$ values of kefir samples produced using buffalo milk were determined to be $0.82 \%$ ( $\mathrm{p}<0.05$ ), 14.26\% ( $<<0.05$ ), 3.05\% ( $<<0.05), 4.50 \%$ and $81.00 \mathrm{mg} / 100 \mathrm{ml}(\mathrm{p}<0.05)$, respectively (Table 2$)$. Acidity and $\mathrm{CO}_{2}$ values of kefir samples increased $(\mathrm{p}<0.05)$, while dry matter $(\mathrm{p}>0.05)$, fat $(\mathrm{p}>0.05)$ and protein contents $(\mathrm{p}<0.05)$ decreased.

The highest acidity value in the samples produced using kefir grains was determined at the end of the 21-days of storage 
Kefir produced from cow and buffalo milk

Table 1. Probability values (p-values) for all main effects and interactions of chemical analysis.

\begin{tabular}{|c|c|c|c|c|c|}
\hline Source of variation & Acidity & Dry Matter & Fat & Protein & $\mathrm{CO}_{2}$ \\
\hline Milk Type & $<0.0001$ & $<0.0001$ & 0.409 & $<0.0001$ & 0.001 \\
\hline Method & $<0.0001$ & 0.631 & 0.409 & $<0.0001$ & $<0.0001$ \\
\hline Storage Time & $<0.0001$ & 0.423 & 0.198 & $<0.0001$ & $<0.0001$ \\
\hline Milk Type $\times$ Method & 0.157 & 0.847 & 0.173 & 0.182 & 0.47 \\
\hline Milk Type $\times$ Storage Time & 0.985 & 0.999 & 0.992 & 0.945 & 0.950 \\
\hline Method $\times$ Storage Time & 0.826 & 1.000 & 0.916 & 0.200 & 0.632 \\
\hline Milk Type $\times$ Method $\times$ Storage Time & 0.120 & 1.000 & 0.992 & 0.738 & 0.992 \\
\hline
\end{tabular}

Table 2. Lsmeans values for milk types, methods, storage time and interactions on chemical analysis.

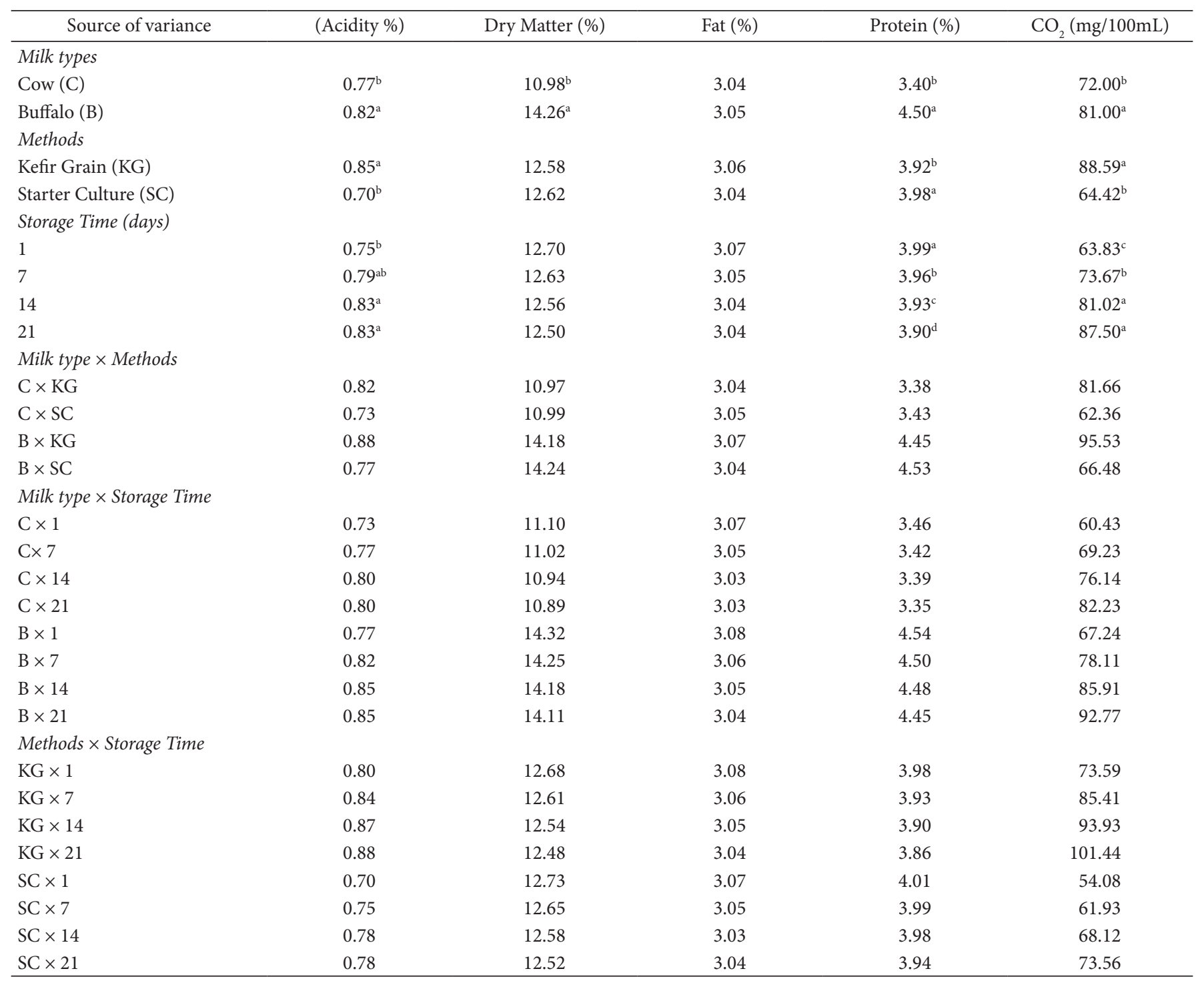

C: Cow Milk, B: Buffalo Milk, KG: Kefir Grains, SC: Starter Culture. Means within a column with different letters are significantly different $(\mathrm{p}<0.05)$.

$(\mathrm{p}<0.05)$ (Table 2). Due to the high initial dry matter content of the buffalo milk, a higher dry matter content was determined during storage compared to the kefir samples produced with cow milk. $\mathrm{CO}_{2}(\mathrm{p}<0.001)$ levels were higher in samples produced with kefir grains due to their yeast content. During fermentation in the production of kefir alcohol and $\mathrm{CO}_{2}$ are formed. Similarly, Barukčić et al. (2017) found higher $\mathrm{CO}_{2}$ content in kefir produced by kefir grains.
The acidity values of the kefir samples produced from buffalo or cow milk using kefir grains or starter culture ranged between 0.70 and $0.80 \%$ at the beginning of storage $(\mathrm{p}<0.05)$ Gul et al. (2015) reported higher values while Kezer (2013) reported similar values. Acidity values of the samples continuously increased during the 21-day storage $(\mathrm{p}<0.05)$. Similarly, Ertekin (2008) determined that the titratable acidity values of the kefir samples gradually increased until the 14 th day of the storage period. 
Higher acidity values were found in kefir samples produced using buffalo milk and kefir grains. Gul et al. (2015) reported that acidity values were higher in the kefir samples produced using kefir grains and buffalo milk. Previous studies showed that the yeast in kefir grains limits the multiplication of lactic acid and acetic acid producing lactic acid bacteria. A significant amount of the acidity in the kefir was due to nitrogenous substances or organic acids, which resulted from the degradation of lactose and nitrogenous substances emerging from the metabolism of lactic acid and proteolytic bacteria during the fermentation.

At the beginning of storage, the dry matter values of the samples produced with cow or buffalo milk using kefir grains or starter culture were between $10.89 \%$ and $14.32 \%$ (Table 2 ) $(\mathrm{p}<0.05)$. The differences in the dry matter values between the samples were seen due to the initial values of the milk used in kefir production. Similarly, Öner et al. (2010) reported that the dry matter content of kefir produced from cow, sheep, or goat milk changed according to the milk type. The study showed that the kefir produced from buffalo milk contained a higher dry matter content than the kefir produced from cow milk. This rate was associated with the fact that the general chemical components of buffalo milk differed from those of cow milk. Buffalo milk had higher contents of dry matter, protein, and lactose (Abd El-Salam \& El-Shibiny, 2011).

The protein content of the kefir samples changed between $3.46 \%$ and $4.54 \%(\mathrm{p}<0.05)$ on the 1 st day of storage, and it was between $3.35 \%$ and $4.45 \%$ on the last day of storage (Table 2). Halle et al. (1994) determined that the protein content of the kefir samples which they produced ranged from $3.10 \%$ to $4.72 \%$. The differences in the protein content of kefir samples were associated with the differences among various types of milk samples used in production. The protein content of kefir samples decreased during storage $(\mathrm{p}<0.05)$.

The proteolytic effect of microbial activity in kefir may explain the decrease in protein content of kefir samples during storage. Similarly, Ertekin (2008) found a decrease in protein content during storage of kefir samples produced from kefir grains or starter cultures. In the present study, the protein values were lower in the kefir samples produced using kefir grains. The protein content of kefir samples produced using kefir grains and those produced using starter culture was 3.92\% and $3.98 \%$ respectively.

Carbon dioxide and alcohol emerged as results of metabolic activities of yeast were the most important components of kefir. At the beginning of the storage, carbon dioxide concentration in the samples changed between 60.43 and $67.24 \mathrm{mg} / 100 \mathrm{~mL}$. The carbon dioxide values in the samples increased during storage $(\mathrm{p}<0.05)$. The present study was in parallel with the study by Alpkent \& Küçükçetin (2000), who found that the carbon dioxide values in kefir samples stored at different temperatures increased approximately 18-fold during the 21-day of storage period.

Carbon dioxide concentrations in kefir samples made with buffalo milk during storage were found to be higher. Kefir grains had a considerable effect on the carbon dioxide content (Table 2). Similarly, Özer et al. (2000) reported that carbon dioxide content was lower in samples produced using a starter culture. This result can be attributed to the higher carbon dioxide production by yeast in kefir grains. A study by Yildiz (2009) reported that high carbon dioxide content was found in kefir samples that underwent a second fermentation procedure using $0.5 \%$ yeast culture. Along with its positive effect on the taste and aroma, carbon dioxide content is used to classify kefir as light, mild and heavy.

\subsection{Microbiological analysis}

Table 3 shows all factors and interactions that affected the microbiological counts of kefir samples. Milk type had no significant effect on the microorganism counts of the samples except for Lactococci and L. acidophilus counts ( $<$ 0.05) (Table 4). Method $\times$ Storage Time interaction had a significant effect on Leuconostoc ( $\mathrm{p}<0.05)$, L. acidophilus $(\mathrm{p}<0.0001)$ and, yeast counts of the samples $(\mathrm{p}<0.002)$.

Milk type $\times$ method $\times$ storage time interactions during storage significantly $(\mathrm{p}<0.05)$ affected the Lactobacilli counts of the samples. Lactobacilli, Lactococci, Leuconostoc counts ( $\mathrm{p}<0.05)$ were higher and L. acidophilus and yeast-mold counts were lower in samples produced using starter culture. Following the increase in the microorganism counts of the samples during storage for 14 days, the levels decreased except for L. acidophilus $(\mathrm{p}<0.05)$ (Table 4). During the 21-days storage period, Lactobacilli (8.52 log CFU/mL) and Lactococci (8.84 log CFU/mL) were higher in kefir produced using buffalo milk and starter culture, while the L. acidophilus (6.41 log CFU/mL) counts were higher in samples produced using cow milk and starter culture. Yeast counts were higher in samples produced using buffalo milk and kefir grains (Table 4). Similarly, Gul et al. (2015) found a higher number of yeasts in kefir made with buffalo milk in their study. They reported that this difference was due to the differences in minor components between milk types.

Table 3. Probability values (p-values) for all main effects and interactions of microbial analysis.

\begin{tabular}{|c|c|c|c|c|c|}
\hline Source of variation & Lactobacillus & Lactococcus & Leuconostoc & L. acidophilus & Yeast \\
\hline Milk Type & $<0.0001$ & 0.094 & 0.001 & 0.274 & $<0.0001$ \\
\hline Method & $<0.0001$ & $<0.0001$ & $<0.0001$ & $<0.0001$ & $<0.0001$ \\
\hline Storage Time & $<0.0001$ & 0.001 & 0.001 & $<0.0001$ & $<0.0001$ \\
\hline Milk Type $\times$ Method & 0.54 & 0.575 & 0.636 & 0.274 & 0.508 \\
\hline Milk Type $\times$ Storage Time & 0.074 & 0.281 & 0.659 & 0.842 & 0.501 \\
\hline Method $\times$ Storage Time & 0.480 & 0.207 & 0.024 & $<0.0001$ & 0.002 \\
\hline Milk Type $\times$ Method $\times$ Storage Time & 0.016 & 0.619 & 0.894 & 0.842 & 0.353 \\
\hline
\end{tabular}


Table 4. Lsmeans values for milk types, methods, storage time and interactions on microbial count $(\log \mathrm{cfu} / \mathrm{mL})$.

\begin{tabular}{|c|c|c|c|c|c|}
\hline Source of variance & Lactobacillus & Lactococcus & Leuconostoc & L. acidophilus & Yeast \\
\hline \multicolumn{6}{|l|}{ Milk types } \\
\hline Cow (C) & $7.94^{\mathrm{b}}$ & 8.18 & $5.83^{\mathrm{a}}$ & 2.56 & $4.18^{\mathrm{b}}$ \\
\hline Buffalo (B) & $8.36^{\mathrm{a}}$ & 8.33 & $5.50^{\mathrm{a}}$ & 2.63 & $4.92^{\mathrm{a}}$ \\
\hline \multicolumn{6}{|l|}{ Methods } \\
\hline Kefir Grain (KG) & $7.89^{\mathrm{b}}$ & $7.77^{\mathrm{b}}$ & $5.10^{\mathrm{b}}$ & 5.18 & $5.38^{\mathrm{b}}$ \\
\hline Starter Culture (SC) & $8.40^{\mathrm{a}}$ & $8.73^{\mathrm{a}}$ & $6.22^{\mathrm{a}}$ & $>2.0$ & $3.71^{\mathrm{a}}$ \\
\hline \multicolumn{6}{|l|}{ Storage Time (days) } \\
\hline 1 & $7.83^{\mathrm{c}}$ & $7.96^{\mathrm{c}}$ & $5.37^{\mathrm{b}}$ & $2.96^{\mathrm{a}}$ & $3.73^{\mathrm{d}}$ \\
\hline 7 & $8.10^{\mathrm{b}}$ & $8.35^{\mathrm{ab}}$ & $5.83^{\mathrm{a}}$ & $2.71^{\mathrm{a}}$ & $4.38^{\mathrm{c}}$ \\
\hline 14 & $8.51 \mathrm{a}$ & $8.53^{\mathrm{a}}$ & $5.88^{\mathrm{a}}$ & $2.39^{\mathrm{b}}$ & $5.15^{\mathrm{a}}$ \\
\hline 21 & $8.14^{\mathrm{b}}$ & $8.18^{\mathrm{bc}}$ & $5.58^{\mathrm{b}}$ & $2.31^{\mathrm{b}}$ & $4.94^{\mathrm{b}}$ \\
\hline \multicolumn{6}{|l|}{ Milk type $\times$ Methods } \\
\hline $\mathrm{C} \times \mathrm{KG}$ & 7.60 & 7.72 & 5.25 & 5.12 & 5.05 \\
\hline $\mathrm{C} \times \mathrm{SC}$ & 8.28 & 8.64 & 6.41 & $>2.0$ & 3.31 \\
\hline $\mathrm{B} \times \mathrm{KG}$ & 8.19 & 7.83 & 4.96 & 5.26 & 5.73 \\
\hline $\mathrm{B} \times \mathrm{SC}$ & 8.52 & 8.84 & 6.04 & $>2.0$ & 4.11 \\
\hline \multicolumn{6}{|l|}{ Milk type $\times$ Storage Time } \\
\hline $\mathrm{C} \times 1$ & 7.80 & 7.99 & 5.52 & 2.91 & 3.41 \\
\hline $\mathrm{C} \times 7$ & 7.93 & 8.25 & 6.09 & 2.64 & 4.10 \\
\hline $\mathrm{C} \times 14$ & 8.22 & 8.36 & 6.03 & 2.38 & 4.71 \\
\hline $\mathrm{C} \times 21$ & 7.80 & 8.03 & 5.69 & 2.31 & 4.50 \\
\hline $\mathrm{B} \times 1$ & 7.86 & 7.94 & 5.22 & 3.01 & 4.06 \\
\hline $\mathrm{B} \times 7$ & 8.28 & 8.36 & 5.58 & 2.79 & 4.66 \\
\hline $\mathrm{B} \times 14$ & 8.80 & 8.70 & 5.74 & 2.41 & 5.59 \\
\hline $\mathrm{B} \times 21$ & 8.47 & 8.34 & 5.47 & 2.31 & 5.39 \\
\hline \multicolumn{6}{|l|}{ Methods $\times$ Storage Time } \\
\hline $\mathrm{KG} \times 1$ & 7.46 & 7.54 & $4.61^{\mathrm{e}}$ & $5.92^{\mathrm{a}}$ & $4.88^{\mathrm{c}}$ \\
\hline $\mathrm{KG} \times 7$ & 7.91 & 7.78 & $5.20^{\mathrm{d}}$ & $5.43^{\mathrm{b}}$ & $5.22^{\mathrm{b}}$ \\
\hline $\mathrm{KG} \times 14$ & 8.28 & 7.95 & $5.49^{c}$ & $4.79^{c}$ & $5.82^{\mathrm{a}}$ \\
\hline $\mathrm{KG} \times 21$ & 7.92 & 7.83 & $5.12^{\mathrm{d}}$ & $4.62^{\mathrm{d}}$ & $5.65^{\mathrm{ab}}$ \\
\hline $\mathrm{SC} \times 1$ & 8.20 & 8.39 & $6.13^{\mathrm{b}}$ & $>2.0$ & $2.58^{\mathrm{g}}$ \\
\hline $\mathrm{SC} \times 7$ & 8.31 & 8.92 & $6.47^{\mathrm{a}}$ & $>2.0$ & $3.54^{\mathrm{f}}$ \\
\hline $\mathrm{SC} \times 14$ & 8.74 & 9.11 & $6.28^{\mathrm{ab}}$ & $>2.0$ & $4.48^{\mathrm{d}}$ \\
\hline $\mathrm{SC} \times 21$ & 8.35 & 8.54 & $6.04^{\mathrm{b}}$ & $>2.0$ & $4.24^{\mathrm{e}}$ \\
\hline
\end{tabular}

C: Cow Milk, B: Buffalo Milk, KG: Kefir Grains, SC: Starter Culture. Means within a column with different letters are significantly different $(\mathrm{p}<0.05)$.

The Lactobacillus counts of the samples were associated with the microflora in the starter cultures and the kefir grains used in the production. In this study, the starter culture contained Lactococcus lactis Spp. cremoris, Lactococcus lactis Spp. lactis, Lactococcus lactis Spp. lactis var. diacetylactis, Leuconostoc Spp., Debaryomyces hansenii, and Streptococcus thermophilus microorganisms. The structure of kefir grains in terms of microorganism flora showed more diversity than the starter culture Kefir grains have complex microbial species that contain mainly lactic acid bacteria, acetic bacteria, yeasts, and fungi (Zhou et al., 2009).

The Lactobacillus counts in kefir samples were 7.80-7.86 $\log \mathrm{CFU} / \mathrm{ml}$ on the 1 st day of storage and $7.80-8.47 \log \mathrm{CFU} / \mathrm{ml}$ on the last day of storage $(\mathrm{p}<0.05)$. These values were similar to those reported by Yildız (2009).

The Lactobacillus counts of the kefir samples increased until the 14th day of the storage period, and then decreased $(\mathrm{p}<0.05)$.
Similarly, Ylldı (2009) found that Lactobacilli counts of kefir samples increased in the first ten days of the storage and decreased in the following days. Guzel-Seydim et al. (2006) has reported that Lactobacillus counts of kefir slowly increased until the 14th day of storage and partially decreased afterwards. However, a study by Kezer (2013) on the microbiological, physicochemical and sensory properties of kefir reported a decrease in Lactobacillus counts (by 1.5 logs) on the 14th day of storage, which then remained constant.

Lactococcus counts of kefir samples were found to be between 7.99 and $7.94 \log \mathrm{CFU} / \mathrm{mL}$ on the 1st day of storage and between 8.03 and $8.34 \log \mathrm{CFU} / \mathrm{mL}$ on the last day of storage $(\mathrm{p}<0.05)$. Similarly, Gul et al. (2015) reported that Lactococci counts of samples approximately ranged between 6.25 to $8.75 \log \mathrm{CFU} / \mathrm{mL}$. Yildiz (2009) found that the Lactococcus counts of the samples ranged from 5.85 to $9.44 \log \mathrm{CFU} / \mathrm{mL}$ at the beginning of the storage. Garrote et al. (1998) showed that the Lactococci counts 
of kefir produced from kefir grains to be $2.3 \times 10^{9} \mathrm{CFU} / \mathrm{mL}$. This difference was associated with the differences in the content of starter cultures used and kefir grains. Lactococcus counts of kefir samples increased until the 14 th day of storage $(\mathrm{p}<0.05)$, and then showed a decrease. Fontán et al. (2006) reported that following the increase in Lactococci counts in kefir samples produced using starter culture during the first 48 hours of fermentation, the counts first decreased and dropped to zero at 168 hours.

Leuconostoc counts in kefir samples were found to be 5.52 to $5.22 \log \mathrm{CFU} / \mathrm{mL}$ on the 1st day of storage and 5.69 to $5.47 \log \mathrm{CFU} / \mathrm{mL}$ on the last day of storage ( $<<0.05$ ). Gul et al. (2015) reported that Leuconostoc counts ranged from 4.65 to $5.09 \log \mathrm{CFU} / \mathrm{mL}$. Fontán et al. (2006) found the Leuconostoc counts in the range of 6.5-7.0 log CFU/mL. Leuconostoc counts in the kefir samples increased until the 14th day of storage, and then decreased ( $\mathrm{p}<0.05)$. They also reported that Leuconostoc counts increased rapidly during the fermentation phase for 48 hours and then remained stable.

L. acidophilus is a microaerophilic microorganism with significant functional properties (probiotic). L. acidophilus counts ranged between 5.81 and $6.24 \log \mathrm{CFU} / \mathrm{mL}$ in the kefir samples which were produced with the kefir grains using cow or buffalo milk and between 4.61 and $4.62 \log \mathrm{CFU} / \mathrm{mL}$ on the 21 st day of storage $(\mathrm{p}<0.05)$ (Table 4$)$.

The most important yeast species in the production of kefir are Kluyveromyces marxianus, Candida kefir, Torulaspora delbruecki, Saccharomyces cerevisiae, and Saccharomyces delbrueckii. Yeast primarily produces carbon dioxide and alcohol in kefir. Yeast is also effective in the formation of various amino acids and vitamins and the decrease in $\mathrm{pH}$ (Arslan, 2015).

Yeast counts in kefir samples were 3.41 to $4.06 \log \mathrm{CFU} / \mathrm{mL}$ on the 1st day of storage and 4.50 to $5.39 \log \mathrm{CFU} / \mathrm{ml}$ on the last day of storage $(\mathrm{p}<0.05)$. The yeast count of the samples was similar to those reported by Öner et al. (2010) while it was lower than those reported by Yildiz (2009). Yeast count of the samples first showed an increase until the 14th day of storage, then a decrease after the 14th day $(\mathrm{p}<0.05)$. According to Fontán et al. (2006), the yeast count in kefir samples increased continuously during fermentation for seven days. Rea et al. (1996) reported that the initial $10^{3} \mathrm{CFU} / \mathrm{mL}$ yeast counts reached $1.5 \times 10^{6} \mathrm{CFU} / \mathrm{mL}$ after 21 days of storage.

\section{Conclusion}

In this study, the use of buffalo milk as an alternative to cow's milk was investigated in kefir production. In addition, kefir grains and commercial kefir starter culture were used for fermentation of kefir. Chemical properties and microbial contents of kefir were affected by milk varieties and kefir grains or starter culture. Kefir containing buffalo milk and kefir grain produced higher acidity and $\mathrm{CO}_{2}$. More yeast was growth in kefir produced with buffalo milk and kefir grains. It is known that some probiotic yeasts have positive effects on health in kefir.

The use of buffalo milk in the production of kefir provides an alternative to the traditionally produced kefir from cow milk. Specifically, it is thought that the use of defatted milk, which is called kaymak alti in kaymak production, in kefir production will increase both the economic value of buffalo milk and contribute to the variety of products made from buffalo milk. The use of kefir grains is considered to be more suitable for kefir production.

The trend to consume organic and healthy foods is increasing throughout the world and promotes the daily and regular consumption of probiotics. Kefir with enhanced functional properties from adding probiotic bacteria will attract the attention of many consumers. In addition, to resolve the issues in the production of this kefir, new studies and projects should be conducted that provide detailed information on future expectations.

\section{References}

Abd El-Salam, M. H., \& El-Shibiny, S. (2011). A comprehensive review on the composition and properties of buffalo milk. Dairy Science \& Technology, 91(6), 663-699. http://dx.doi.org/10.1007/s13594011-0029-2.

Akarca, G., Çağlar, A., \& Tomar, O. (2016). The effects spicing on quality of mozzarella cheese. Mljekarstvo, 66, 112-121. http://dx.doi. org/10.15567/mljekarstvo.2016.0203.

Alpkent, Z., \& Küçükçetin, A. (2000). Changes in the sensory, physical, chemical and microbiological properties of kefir stored at different temperatures: Milk Microbiology and Additives. Proceedings VI Milk and Dairy Products Symposium (pp. 363-373). Tekirdağ, Turkey: Trakya University Publishing.

Arslan, S. (2015). A review: chemical, microbiological and nutritional characteristics of kefir. CYTA: Journal of Food, 13(3), 340-345. http:// dx.doi.org/10.1080/19476337.2014.981588.

Association of Official Analytical Chemists - AOAC. (2012a). Official Methods of Analysis of AOAC International (Solids (Total) in Milk. 990.20, 19th ed.). Gaithersburg: AOAC.

Association of Official Analytical Chemists - AOAC. (2012b). Official Methods of Analysis of AOAC International (Acidity, Titrimetric Methods. 947.05, 19th ed.). Gaithersburg: AOAC.

Association of Official Analytical Chemists - AOAC. (2012c). Official Methods of Analysis of AOAC International (Fat Content of Raw and Pasteurized Whole Milk. 2000.18, 19th ed.). Gaithersburg: AOAC.

Association of Official Analytical Chemists - AOAC. (2012d). Official Methods of Analysis of AOAC International (Nitrogen (Total) in Milk. Kjeldahl Method. 2000.20, 19th ed.). Gaithersburg: AOAC.

Barukčić, I. L., Gracin, A., Jambrak, R., \& Božanić, R. (2017). Comparison of chemical, rheological and sensory properties of kefir produced by kefir grains and commercial kefir starter. Mljekarstvo, 67, 69-176. http://dx.doi.org/10.15567/mljekarstvo.2017.0301.

Borghese, A. (2012). Buffalo livestock and products. In A. Borghese (Ed.), Pécs (pp. 479). Hungary: Eurofomazione.

Cais-Sokolińska, D., Danków, R., \& Pikul, J. (2008). Physicochemical and sensory characteristics of sheep kefir during storage. Acta Scientiarum Polonorum. Technologia Alimentaria, 7(2), 63-73.

Ertekin, B. (2008). Effect of use of oil substitutes on kefir quality criteria (Master's thesis). Süleyman Demirel Üniversitesi, Isparta.

Farnworth, E. R. (2008). Handbook offermented functional foods (2nd ed.). Boca Raton: CRC.

Fontán, M. C. G., Martínez, S., Franco, I., \& Carballo, J. (2006). Microbiological and chemical changes during the manufacture of Kefir made from cows' milk, using a commercial starter culture. 
International Dairy Journal, 16(7), 762-767. http://dx.doi.org/10.1016/j. idairyj.2005.07.004.

Gao, X., \& Li, B. (2016). Chemical and microbiological characteristics of kefir grains and their fermented dairy products: A review. Cogent Food \& Agriculture, 2(1), 1272152. http://dx.doi.org/10.1080/2331 1932.2016.1272152.

Garrote, G. L., Abraham, A. G., \& De Antoni, G. L. (1998). Characteristics of kefir prepared with different grain [ratio] milk ratios. The Journal of Dairy Research, 65(1), 149-154. http://dx.doi.org/10.1017/ S0022029997002677.

Gul, O., Atalar, I., Mortas, M., \& Dervisoglu, M. (2018). Rheological, textural, colour and sensorial properties of kefir produced with buffalo milk using kefir grains and starter culture: A comparison with cows' milk kefir. International Journal of Dairy Technology, 71, 73-80. http://dx.doi.org/10.1111/1471-0307.12503.

Gul, O., Mortas, M., Atalar, I., Dervisoglu, M., \& Kahyaoglu, T. (2015). Manufacture and characterization of kefir made from cow and buffalo milk, using kefir grain and starter culture. Journal of Dairy Science, 98(3), 1517-1525. http://dx.doi.org/10.3168/jds.2014-8755. PMid:25582588.

Guzel-Seydim, Z. B., Seydim, A. C., Greene, A. K., \& Taş, T. (2006). Determination of antimutagenic properties of acetone extracted fermented milks and changes in their total fatty acid profiles including conjugated linoleic acids. International Journal of Dairy Technology, 59(3), 209-215. http://dx.doi.org/10.1111/j.1471-0307.2006.00265.x.

Halle, C., Leroi, F., Dousset, X., \& Pidoux, M. (1994). Les kefirs. Des Associations Bacte'ries Lactique-Levures. In H. Roissart \& F.M. Luquet (Eds.), Bacte'ries Lactiques: Aspects Fondamentaux et Technologiques (pp. 169-182). France: Lorica ed. Uriage.

Kezer, G. (2013). The effect of fat substitutes on the physicochemical, microbial and sensory properties of kefir made from a mixture of cow and goat milk (Master's thesis). Ondokuz Mayis University, Samsun.

Metin, M. (2012). Milk Technology: composition and processing of milk (Publications No. 33). İzmir: Ege University Engineering Faculty.

Moreno de LeBlanc, A., Chaves, S., Carmuega, E., Weill, R., Antóine, J., \& Perdigón, G. (2008). Effect of long-term continuous consumption of fermented milk containing probiotic bacteria on mucosal immunity and the activity of peritoneal macrophages. Immunobiology, 213(2), 97-108. http://dx.doi.org/10.1016/j.imbio.2007.07.002. PMid:18241694.

Nielsen, B., Gürakan, G. C., \& Ünlü, G. (2014). Kefir: a multifaceted fermented dairy product. Probiotics and Antimicrobial Proteins, 6(3-4), 123-135. http://dx.doi.org/10.1007/s12602-014-9168-0. PMid:25261107.
Öner, Z., Karahan, A. G., \& Cakmakci, M. L. (2010). Effects of different milk types and starter cultures on kefir. Food, 3, 177-182.

Özer, B., Atasoy, A. F., \& Özer, D. A. (2000). Study on the production of kefir by using two phase fermentation and starter. Milk microbiology and Additives. I Proceedings VI. Milk and Dairy Products Symposium (pp. 354-362). Tekirdağ, Turkey: Trakya University Publishing.

Rea, M. C., Lennartsson, T., Dillon, P., Drinan, F. D., Reville, W. J., Heapes, M., \& Cogan, T. M. (1996). Irish kefir-like grains: their structure, microbial composition and fermentation kinetics. The Journal of Applied Bacteriology, 81(1), 83-94. http://dx.doi. org/10.1111/j.1365-2672.1996.tb03286.x.

Tomar, O., \& Akarca, G. (2018). Use of cow and buffalo milk with different fat contents for production of Kefir drinks with Kefir grain and starter culture: their protein and tyrosine contents during storage. Akademik Glda, 16(4), 395-402. http://dx.doi.org/10.24323/ akademik-gida.505508.

Tomar, O., Akarca, G., Beykaya, M., \& Çağlar, A. (2018). Some characteristics of erzincan tulum cheese produced using different probiotic cultures and packaging material. Kafkas Üniversitesi Veteriner Fakültesi Dergisi, 24(5), 656-663. http://dx.doi.org/10.9775/ kvfd.2018.19596.

Turkey. Ministry of Agriculture, Forest and Village Affairs. General Directorate of Protection and Control. (1988). Food products examination and analysis methods. Ankara: Ministry of Agriculture, Forest and Village Affairs. General Directorate of Protection and Control.

Tripathi, M. K., \& Giri, S. K. (2014). Probiotic functional foods: Survival of probiotics during processing and storage. Journal of Functional Foods, 9, 225-241. http://dx.doi.org/10.1016/j.jff.2014.04.030.

Wojtowski, J., Dankow, R., Skrzypek, R., \& Fahr, R. D. (2003). The fatty acid profile in kefirs from sheep, goat and cow milk. Milchwissenchaft, 58, 633-636.

Yildı, F. (2009). The effect of different fat ratios and different starter cultures on the qualities of kefir (Ph.D. thesis). Ankara University, Ankara.

Yilmaz-Ersan, L., Ozcan, T., Akpinar-Bayizit, A., \& Sahin, S. (2018). Comparison of antioxidant capacity of cow and ewe milk kefirs. Journal of Dairy Science, 101(5), 3788-3798. http://dx.doi.org/10.3168/ jds.2017-13871. PMid:29477522.

Zhou, J., Liu, X., Jiang, H., \& Dong, M. (2009). Analysis of the microflora in Tibetan kefir grains using denaturing gradient gel electrophoresis. Food Microbiology, 26(8), 770-775. http://dx.doi.org/10.1016/j. fm.2009.04.009. PMid:19835760. 